\title{
The Learning Climate for Administration Students
}

\author{
Mark Ezell, Ph.D. \\ Associate Professor \\ University of Kansas \\ School of Social Welfare \\ Roslyn H. Chernesky, DSW \\ Professor \\ Fordham University \\ Graduate School of Social Service \\ Lynne M. Healy, Ph.D. \\ Professor \\ University of Connecticut \\ School of Social Work
}

This paper was originally presented at the Administration in Social Work Editorial Board Institute, Charleston, SC, June 2002. The authors would like to thank Mike Austin for his very useful comments on an earlier draft of the paper. 


\begin{abstract}
The percentage of MSW students specializing in administrative practice has been declining in recent years, as has the percentage of NASW members who identify themselves as administrators or supervisors. One of many possible explanations for these trends is that schools of social work are inhospitable environments for social work administration. The research reported in this article sought to determine if administration students perceive the school climates at three different universities to be hostile to social work management practice, and, if so, to explore the dynamics of how these climates influence the choices made and the education of administration students. We found that at all three schools, nonadministration students were perceived to be critical of students who selected administration concentrations and administration as a career path, that majorities of students experienced anti-management comments and attitudes in a variety of forms, and that administration students thought their foundation courses provided inadequate background for their advanced studies. The article concludes with a discussion of the findings and recommendations for change.
\end{abstract}

KEYWORDS: social work administration; anti-management; organizational climate; schools of social work. 


\section{The Learning Climate for Administration Students ${ }^{1}$}

Almost twenty years ago Perlmutter (1984) said that she thought social administrators were an endangered species. As it turns out, what she may have predicted is the declining numbers and endangered status of MSW students who focus their education on administrative practice.

An examination of approximately 25 years of data from the Council on Social Work Education (CSWE) illuminates the enrollment trends of MSW students choosing to specialize in administration (see Figure 1). ${ }^{2}$ From 1975 until 1982 there was a sharp growth trend not only in the number of students specializing in administration but the percent of all MSW students selecting administration concentrations as well. In 1982, there were almost 1400 students specializing in administration, $6.5 \%$ of all MSW students. After the peak year of 1982, both the number and percent dropped for several years followed by a short rise, peaking in 1988 at 1,232 students. After 1988, and discounting 1998 which seems to be an aberration, the number of MSW students in an administration concentration has remained relatively stable at approximately 1000 per year. The percent of all MSW students selecting administration specializations, however, has been declining since 1987. From 1995 through 2000, the trend seems to remain steady at just above 3\%, half what it was in the peak year of 1982 .

Figure 1 here

\footnotetext{
${ }^{1}$ Throughout this paper the terms "administration" and "management" are used synonymously, as are "administrator" and "manager."

${ }^{2}$ Data for this figure came from the Council of Social Work Education's annual publication, Statistics on Social Work Education in the United States. Every year there is a table that reports the number of MSW students enrolled by primary methods concentration. Categories such as the following are used: Direct practice; Community organization and planning; Administration or management; Combination of C.O. and Planning with Administration or Management, etc. In addition, those categories are broken down by "Concentration Framework" - Methods Only or Methods Combined with Field of Practice or Social Problem. Data reported here were taken from both concentration frameworks and includes only the students identified as "Administration or Management."
} 
Besides data on MSW students, there is recent information on the number of practitioners who identify themselves as administrators. Gibelman and Shervish (1997) report that $15.5 \%$ of working NASW members identify administration as their primary function. This is a decline from $17.7 \%$ in 1988 . Similarly, $5.5 \%$ say supervision is their primary function where $6.4 \%$ said the same in 1988. They explain that there are a large number of explanations for these trends such as nonsocial workers being hired for these roles or the possible tendency of social workers in these roles not becoming members of NASW. However, they finally conclude, "the direction of the NASW membership ... is clearly away from macro practice” (p. 166).

These trends lead to the undesirable situation where fewer and fewer of the social workers in managerial positions in our agencies will have received specialized graduate training for these roles, if they are social workers at all. It is far from a new phenomenon to find social workers in management positions who do not have relevant training since it has long been widely held in the social work profession that direct service experience is the essential prerequisite for social work administration (Patti, 1983). The decline in the number of administration students portends a worsening of this situation, however, and this is happening just when we are beginning to see empirical evidence about the connections between agencylevel factors and client outcomes, factors that trained administrators have learned how to influence. Glisson and Hemmelgarn (1998), for example, established an empirical correlation between agency climate and client outcomes, and Yoo (2002) identified several organizational conditions that influence case managers in negative ways (e.g., low pay, lack of leadership), but also found that those negative conditions may be buffered by such things as supervisor and coworker support that help achieve positive outcomes. 
These trends may reflect the national struggle that administration has encountered in order to be viewed as a legitimate modality of social work practice in the profession and to gain a respected place in MSW curricula. For example, twenty years ago, Patti (1983) began his book on social welfare administration with the following statement: "Although social workers have long been extensively involved in administering social welfare organizations, both public and private, the profession of social work has been slow - and for the most part reluctant - to recognize administration as a legitimate expression of professional practice" (p. 1). Similarly, the most recently published book on social administration expresses a comparable statement: "Administration has been important in the social services since before the Elizabethan Poor Law of $1601 \ldots$ Yet, administrative content has never played a particularly large or important role in the social work curriculum" (Lohmann \& Lohmann, 2002, p. 8). With these juxtaposed perceptions being so similar but recorded twenty years apart, coupled with the data on MSW students and social work practitioners, we are left wondering how much, if any, progress has been made reducing the "abiding resistance to recognizing it [social work administration] as a professional method of practice" (Patti, 1983, p. 10).

There are a number of possible explanations for the decline in the number and percent of students concentrating their studies in social administration and planning for careers in social service management. Some have suggested that schools of social work are unable to offer adequate curriculum to prepare graduates for management positions. At least some published outcome studies of administration concentration graduates and a national study on the adequacy of the administration curriculum by McNutt (1995) suggest otherwise. McNutt concluded that, although the comprehensiveness of macro curricula could be improved, the social work curriculum "does not explain the declining fortunes of macro social work education" (p. 73). In 
fact, he found evidence of what he called the "maturing of the field of social administration" ( $p$. 71). Likewise, based on a long-term follow-up of one school's administration concentration graduates, Martin, Pine and Healy (1999), after examining skill acquisition and employment, concluded that a school of social work with a management concentration "can prepare managers who are employable in significant managerial positions and who have confidence in their preparedness for managerial work” (p. 90).

As McNutt (1995) concluded: "If we are to understand the source of our (macro practice) deteriorating position, it will be necessary to explore the institutional context of social work education, particularly the social work professional organizations and schools of social work. It is here that the fate of macro social work education, and ultimately the social work profession, will be decided" (p. 73).

Other explanations for the decline relate more directly to a pervasive anti-management ideology (Ezell, 1990) within the social work profession and within schools of social work. Several of the alternative explanations are summarized below.

- State licensing laws require applicants to demonstrate clinical social work knowledge in the qualifying exams and may require specific clinical coursework and/or experience; this can discourage students from selecting macro/administration concentrations (Pine \& Healy, 1994).

- The CSWE standards that require a generalist foundation course of study in schools of social work is often heavily micro-oriented and may not prepare students for specialization in macro-practice. 
- The growth in the number of masters degrees in nonprofit management could be attracting potential administration students away from the profession, along with continued competition from MPA and MBA degrees. There has not been much concern expressed about the increasing number of social service agencies led by executive directors with training and experience outside the social work profession.

- High quality administration practicum placements are difficult to find and keep. There is a relatively small number of social work administrators who are willing and able to provide field supervision. Chronic budget cuts make administrative jobs more demanding and time consuming, leaving little, if any, time for supervision. Funding crises create agency turmoil into which many social work administrators are reluctant to bring students. Many of the administrators who are willing to take students were not trained in administration, and, therefore, are unable to provide a high quality practicum experience.

Certainly other explanations might be suggested. The following statement by Mabrey, Thompson and Halseth (1996) resonated with a sizable body of anecdotal data accumulated by the authors in their many years of working with administration students.

The possibility exists that within social work a negative attitude and a hostile environment cast a shadow over macro-level education. This shadow may manifest itself as faculty provide formal and informal academic and career advising to students, as field instructors and other practitioners offer advice, and as fellow students, who reject macro practice, express a negative attitude about the values of students choosing a macro track (p. 3).

This paper explores the possibility that is raised in the quote above, that schools of social work may be hostile environments for macro-level education. The findings from this exploratory study provide a foundation for a more comprehensive national study in the future. The first section of the paper includes a literature review that discusses the factors that influence student 
selection of concentrations, the important beliefs that are part of an anti-management ideology in social work education, and the nature and definition of organizational climate. The next section describes the research approach used including the sample and data collection methods; study limitations are outlined as well. The findings are presented in the following section, both in a school-by-school manner as well as cross-school trends. The last two sections of the paper include, first, a discussion of the findings that raises many questions for future research, and second, several recommendations for schools and the profession.

\section{$\underline{\text { Literature Review }}$}

While little research has been done on selection of specializations, Schwartz and Dattalo (1990) identified three factors that are likely to influence student selection of their method concentration: "professional ideologies," the job market, and the available curriculum at their school of choice. Neugeboren (1986) earlier wrote that availability of concentrations and perceptions about the job market shape student interest in micro or macro. In this paper, we focus on the impact of professional ideologies, particularly those ideologies that may be hostile to social administration and/or to its inclusion in the curriculum as a specialization. In introducing a paper on this topic more than a decade ago, Ezell (1990) defined ideologies as "composed of assumptions, beliefs, stereotypes, values and orientations" (p. 2); furthermore, their "elusiveness and near invisibility make them very powerful, difficult to identify, and resistant to change" (p. 2). Ezell suggested that negative perceptions about social work managers hurt recruitment of students to the field of social administration. If those who aspire to administration as a career are made to feel defensive about their choice, no wonder it is difficult to recruit social work students to management concentrations. Ultimately, these ideologies may 
well shape perceptions about the job market and determine whether macro specializations are offered at schools of social work.

Inhospitality and hostility toward management have been referred to as antipathy or antimanagement norms (Turem, 1986), an abiding resistance to management (Patti, 1983), and professional parochialism, reciprocal jealousy, and a turf guarding mentality (Page, 1978). While hostility may exist, culture clash may more accurately describe some of the friction between clinicians and administrators. Lagay (1983) wrote of how social work's two cultures, clinicians and managers, "often have trouble speaking to one another through a shared frame of reference in any more than the most global terms" (p. 277). In their illuminating article on ideological conflict among key domains in non-profit organizations, Kouzes and Mico (1979) discuss the disjunctures between management and direct service workers, explaining that these two domains have separate identities and contrasting norms.

As authors have explored the role of ideology in intra-professional conflicts in social work, and as we consider its impact on student decision-making, there are two related sets of beliefs that are particularly important. The first is "micro before macro," the idea that the only legitimate route into administrative positions is after having experience on the front lines of the profession. The second powerfully held belief is that micro or clinical social work is the only true legitimate expression of social work - administration is not "real" social work. Together they contribute to anti-management views and climates in schools.

$\underline{\text { Micro }}{ }^{3}$ Before Macro. Patti and Austin (1977) identified "a long-held belief in social work that learning about administration is simply a matter of superimposing a layer of

\footnotetext{
${ }^{3}$ The term "micro social work" or just "micro" is used in this paper to mean direct services, casework, or clinical social work.
} 
management knowledge and skill on an intact foundation of clinical competence" (p. 269). Schwartz and Dattalo (1990) found that this belief has been complicated by licensing and by growth of private practice. In selecting their concentration, students may want to hedge their bets for reasons of employment, or, they may be influenced by the dominant view that they must obtain micro skills, even if they are interested in administration. Their study asked students at one school of social work to rank factors affecting their decision not to select a macro practice specialization. Out of a total of 158 MSW students, 17 were macro majors; another 37 said they seriously considered macro as a concentration, but ultimately chose micro practice. Schwartz and Dattalo surveyed those who considered, but did not select macro concentration on the reasons for their choice. The most significant factor, ranked important by $69 \%$, was the desire to get clinical experience before macro. Second was being sure to be prepared for licensure with $61 \%$ ranking this important. Concerns over the availability of jobs in macro practice was reported by $30 \%$, and $22 \%$ reported lack of information about macro practice. Fear of isolation from the majority of (micro) students was important or somewhat important to $19 \%$. They note that whether one accepts the argument that prior direct service experience is necessary for effective macro practice, it is important to note that students in this study believe this to be true and appear to adjust their educational plans accordingly.

Similarly, Pine and Healy (1994) also found that students adjust their educational plans out of worry about clinical licensing. "Those entering the profession are so concerned about qualifying for licenses that they will modify their career aspirations, direct their talents, and select an aspect of the profession in which they have less interest and perhaps less aptitude to ensure that they remain eligible for licensing" (p. 277). 
In another study of the question, Neugeboren (1986) surveyed deans of schools of social work and asked whether they agreed with the following: "Direct service skills is a necessary foundation for effective performance of administrative roles and functions" (p. 5). Of those responding, $63 \%$ agreed with this statement, showing clear adherence to the ideology of micro before macro by leaders in social work education. Furthermore, he found that schools led by deans who agreed had fewer students enrolled in macro practice concentrations. An earlier article by Biggerstaff (1978) found some evidence that direct service agencies may also consider the extent of prior micro experience and education when hiring and promoting into macro positions. Austin (2000) predicts that recent trends may well reinforce the notion that all social workers should begin as direct service workers and that direct service will remain an important factor in promotions to management jobs.

Micro Practice As the Only Legitimate Social Work. Perhaps more significant than "micro before macro" is micro as the sum total of social work. The ideology that only direct practice is legitimate social work is still present in many quarters. "This micro ideology is manifest in national professional organizations, publications, and meetings" and licensing regulations and exams are "overwhelmingly or exclusively direct-service oriented" (Mabrey et al., 1996, pp. 6-7).

Practitioners who believe that micro social work is the real social work are likely to pass this view on to future social workers. It is not surprising that students report a lack of knowledge about practice modalities other than direct service (Neugeboren, 1986; Schwartz \& Dattalo, 1990). Students get career advice from practitioners and the majority of practitioners with whom they interact are in direct service or, even if not, were trained in direct service. 
Neugeboren (1986) identified "ideological and political forces operating in the social work education system" (p. 1) as the reason for low enrollment in administration concentrations. Although much evidence exists that the field needs agency leaders with strong administrative skills, social work curriculum continues to emphasize direct practice. In his article, he argues that the move toward a generic or generalist curriculum was in fact a solidification of direct practice emphasis, as the content of most generalist programs stress micro rather than macro practice. Thus, in the drive to establish a single, unified profession through a generalist foundation curriculum at both the BSW and MSW levels, generalist practice and education are overwhelming micro. Compounding this is the increased popularity of "advanced clinical generalist" as a graduate concentration or specialization (Austin, 2000).

Neugeboren, however, is not convinced that it is entirely ideology at work; rather, the issue may be turf protection by those faculty who have invested their own careers in micro social work teaching. "If generic social work is similar to the micro area of social work practice, then the development of an area of practice that claims jurisdiction for all of social work may be an effective strategy for maintaining the power base for the direct service oriented faculty. Advocating the need for one profession may be a morally defensible strategy for maintaining the status quo" (1986, p. 8).

One study of how graduates assessed their preparation for administrative practice (Martin et al, 1999) found that administration concentrators said that they learned little in the way of useful interpersonal skills in the foundation curriculum, as the content taught was focused on individuals and families. Thus, the authors concluded that "because the large majority of social work students select micro practice specialties, the concomitant focus of faculty and texts on micro practice models, and because of the need to learn from the simple to the complex, macro 
practice examples are mostly excluded from foundation practice curricula" (Martin et al., 1999, p. 92).

The most extreme version of the "direct service is the real social work" argument may be the position that the values of social work administrators are incompatible with social work's client-centeredness (Gummer, 1987). Social work managers are perceived to over-emphasize outputs and outcomes as opposed to process. Thus, this extreme view explicitly says administration is not and should not be promoted as a social work methodology because it stands for negative values. This is similar to recent writing on anti-managerialism (Ife, 2001; Rees \& Rodley, 1995). The term managerialism refers to the valuation of efficiency and faith in the tools and techniques of management. The critics of managerialism, just like many social workers, think that this faith is over-valued to a degree that crowds out more important human and service effectiveness values (Edwards, nd).

Attitudes regarding social work administration, such as those discussed above, are both powerful shapers and elements of the organizational climates in which students pursue graduate education. "Organizational climate is widely defined in terms of employees' perceptions of their work environment" (Glisson, 2000, p. 196). For our purposes, we prefer to broaden this definition to include the attitudes of all organizational members, not just employees. Since schools of social work involve multiple types of interacting constituents, ranging from students to faculty and field instructors to staff, an inclusive definition of organization climate is more useful. Any given organizational climate is an aggregation, and possibly a synergistic combination, of individual psychological climates (i.e., an individual's "perception of the psychological impact of the work environment on his or her own personal well-being" (Glisson, 
2000, p. 197)). It is important to note that our interest in organizational climate does not stop at schools of social work but also extends to practicum sites.

The nature of the organizational climates are important not only because of their potential impact on organizational members' behaviors and attitudes but also because of their influence on organizational effectiveness and efficiency as well. When Glisson and Hemmelgarn (1998) discuss the importance of the attitudes of service providers on the outcomes of services, they point out "the effectiveness of these services depends heavily on the relationships formed between service providers and the people who receive the services" (p. 404), they use as a parallel the relationships between teachers and their students. MSW students form multiple relationships with instructors, both classroom and field, as well as their classmates who also serve as informal teachers, especially those who come back to school with experience. If antimanagement attitudes are prevalent among many faculty, students, and field instructors, to what extent is the organizational climate of schools inhospitable to those members holding different viewpoints? To what extent will students who are interested in administration feel marginalized in an inhospitable organizational climate, question their decisions, and find the effectiveness of their education compromised?

Thus, the primary research question for this exploratory study is: To what degree do organizational climates in schools of social work reflect anti-management ideologies and how do these climates influence the behaviors and thinking of organizational members, especially students?

\section{$\underline{\text { Research Methods }}$}

This exploratory study seeks to determine if students perceive their school climates to be hostile to the management practice of social workers, and, if so, to explore the dynamics of how 
these climates influence the education of macro students. For this study, we focused on students who had selected administration concentrations at three different universities, referred to here as School A, School B, and School C. We think that administration students are more likely than clinical students to be sensitive to the existence and influences of anti-management climates.

Schools A and B used survey methodology while School C used a focus group approach. Student feedback was solicited on issues such as the reactions of classmates and faculty to the students choice of concentration and career direction, the nature and frequency, if any, of antimanagement comments and attitudes, and the amount of administration or macro content in their foundation courses.

The researcher at School A sent 18 e-mail surveys a few days before graduation and received 11 usable responses (65\%). All respondents were women and all but two had been in the advanced standing program by entering the second year of the MSW program. This last fact is important because most of this subsample were not exposed to the school's climate during the first year of the foundation curriculum and therefore could not comment on the MSW foundation courses.

At School B, surveys were distributed both in print and on-line to 27 students in the administration concentration who had or were completing at least the first year of field work (all students at School B do two field placements). Of those receiving surveys, 17 students returned usable responses for a response rate of $63 \%$. In addition, a follow up discussion was held with concentration students. Respondents to School B's survey differ from those in School A, as only a few of the Administration concentration students at School B were BSWs (i.e., advanced standing). Thus, most responding students had taken foundation courses. All administration 
concentration students at School B also have two or more years of prior social service experience.

At School C, discussions were held with students during the last administration class of the final semester as part of an overall summary of the administration courses and curriculum. The instructors for the two sections (10 students in one; 18 in the second) presented two broad questions for student response: (1) As an administration student, have you found that other students, non-administration faculty, foundation faculty, and/or foundation year advisors supported your choice of administration and your career goals? (2) There are some who claim that social work management isn't "real social work." Have you encountered this view in your classes or in your fieldwork? Have anti-management comments ever been made in your classes or in your field placement?

The nonrandom selection of universities and administration students as well as varying data collection methods limits our ability to fully test the hypothesis that climates inhospitable to social administration not only exist in our schools but also influence career and academic paths of students. At Schools A and C, feedback from students was collected when the students were virtually finished with the administration curriculum. At School B, however, information was gathered at an earlier point in the program. As a result of these differences, the findings reported below should be considered tentative until more research can be implemented.

\section{Findings}

This section presents the findings of student feedback collected at the three schools of social work. The specific school-by-school findings are shown in Tables 1 and 2. Table 1 shows what students said about the reactions of others when they chose administration both as a concentration and as a career; this table also shows their perceptions about anti-management 
comments and attitudes at their schools. Table 2 shows the specific findings about student perceptions of administration and/or macro content in their foundation courses as well as other observations and thoughts they had on the topics covered in the survey. Since the specific findings are shown in the tables, most of the discussion that follows focuses on the themes we observed across the three schools. When combining the sub-samples from each school there were a total of 56 respondents. Numerous student comments are included below to illustrate the findings.

Tables 1 and 2 here

$\underline{\text { Reactions to Students Choosing Administration. Even though the organizational }}$ climates at the three schools may differ, the one consistent finding across the three universities is that about half the respondents said their classmates criticized them for their choices. One student said, for example, "Most clinical students questioned why someone would want to get an management focused degree if most clinical students become administrators without the coursework," while another said that "Clinical students do not feel that administrative students would be better administrators than clinical students."

It was interesting that students at School B reported mixed support for their choice of the administration concentration before they started the program, but once at the School, they were less likely to find support for their career directions. They report that their clinical classmates lack understanding about what management is, feel resentment over different assignments given to administration concentration students in the field, and view administration students as different, strange, or even arrogant. 
School C's climate was consistently perceived as anti-management across all constituencies (faculty, field, and other students). They said it was frequently pointed out that the correct and/or only career path to administration was from clinical social worker to supervisor and then to manager, and that it was possible for anyone to become an administrator over time.

Anti-Management Comments and Attitudes. A majority of students at all three schools reported hearing anti-management comments, perceiving anti-management attitudes, and hearing statements that administration is not social work. Some students at one of the schools were told that if they wanted to be administrators then they should not be in a social work school but should be going for an MBA or MPH. One respondent reported, "some students in one of my classes made comments that the administration track should not make someone more or less eligible for a management position." Other students reported that some of their clinical classmates had wondered why someone would want to do administration since it is so boring and/or difficult work. Another student was asked how she would be qualified to manage a social agency when she will not be qualified for an entry level (clinical) position. At one school, students reported the extreme situation where a professor remarked in class that "administrators really are not human and they have lost all touch with social work."

Perceptions of Foundation Courses. Students at all three schools were very critical of the way their foundation courses failed to prepare them their study in administration. The use of examples from management or macro practice in foundation courses was minimal at best. A number of students voiced the opinion that the lack of relevant examples provided by faculty members is evidence of anti-management attitudes. 
Other Student Observations. In the process of collecting information about possible anti-management attitudes at three schools of social work, other relevant information surfaced. An optimistic finding from all three schools was that almost all administration concentration students had no second thoughts about their choice of the administration concentration, notwithstanding the experiences reported above. Many students were strongly positive and reported that their convictions about the need for and importance of social work administration had been strengthened through their educational experiences. One student said, for example, "The need to understand and manage resources effectively is quite profound and I am looking forward to contributing to it," while another added, "I have never had any second thoughts and have actually come to realize more intensely what a positive decision I made three years ago." These students also believed strongly that social service agencies and programs should be managed by social workers.

\section{$\underline{\text { Discussion }}$}

The extent to which anti-management sentiments were expressed and experienced by administration students in this small sample at three graduate social work programs seems to provide preliminary evidence that schools may have inhospitable and hostile environments that make it difficult for students to select and pursue their educational and career path in administration. In some ways, these findings are even more remarkable when one considers that each of the schools in the sample has had a long-standing concentration in administration with tenured teaching faculty who assume responsibility for the development and implementation of the concentration. In fact, in all cases, these faculties were somewhat shocked to learn how pervasive student sentiments were about their school environments. 
We believe this exploratory study begins to document the existence of anti-management organizational climates, and, more specifically, negative psychological climates. In other words, these graduate social work students perceived that their school environment could pose a threat to their self-images and careers. The most extreme example of this is that in one school, administration students who were completing their graduate studies expressed doubt that they had made the correct choice and began to voice the same kinds of concerns that they had been hearing all along that they would be unable to find a job or pass the state licensing exam.

Because the data collected here only reported on the shared perceptions and experiences of management students, we cannot fully describe or analyze the climate of each school without more information from other organizational members. Of course, this study could not determine whether the schools actually posed a threat to current or future administration students, nor could this study document that these schools actually represented a hostile or inhospitable environment. Future research on both the culture and climate of schools, including what takes place in schools and the norms and values that govern the way things are done, is needed to determine the actual school environments.

Earlier in this article, some possible explanations for the inhospitable and hostile environments were offered. Because the study reported on here was limited in scope, it was unable to provide additional insights into the causes of how negative school climates emerge over time. However, it is possible now to begin to frame a future research agenda that could involve all schools with management specializations. In fact, why organizations develop different climates, how those climates are maintained over time, and how those climates impact the day-to-day operations of organizations and behaviors of individual members are questions of concern to organizational theorists and researchers in general. By drawing upon their thinking 
about how climates develop in organizations, we may want to consider the following research strategies to assess the organizational climates of schools of social work:

- Organizational environments are a product of history and experience related to dominant norms and values that are strengthened with the addition of new and significant organizational members that share the perspective. To what extent are schools of social work dominated by the interests of clinical social work despite decades of efforts -spearheaded by the CSWE Accreditation Standards -- to broaden the view of social work to effectively integrate generalist social work practice? Do schools include a majority of faculty, administrators, and agency constituents who continue to equate social work with "casework", "therapy" or clinical practice and do not yet see administration as social work practice, even though it was described as a practice method for study in the 1959 Social Work Curriculum Study (Dinerman, 1984)?

- Social work administration graduates find themselves in competition with those in other areas of administration, including non-profit administration and law, who are thought to possess stronger decision-making skills. Fewer and fewer social agencies are administered by social workers today. To what extent is the profession still committed to the notion that agencies should be administered by social workers?

- The professional social work community, especially national and local NASW chapters, has focused considerable energies on obtaining licensing legislation in the past several decades. To what extent have the efforts of the professional organization to serve and protect its clinical members implicitly or explicitly conveyed that being a clinical social worker is being a social worker?

- Members are socialized into the culture and climate of their organizations and thereby affect norms, values, and perceptions. To what extent has the changing nature of the student population, with less time to spend at schools reduced the impact that administration faculty can have on the socialization of students?

\section{Conclusion and Recommendations}

No school of social work would set out to purposely create and maintain a hostile or even unsupportive learning climate for a segment of its student body. Indeed, most social workers 
would find the presence of a climate that participants experience as hostile to be inconsistent with social work values, although some might dismiss elements of what students report as hostile to be good-natured intra-professional rivalry. Nonetheless, if students perceive their learning climate to be hostile or unsupportive, then a problematic condition may certainly exist. The small study reported here suggests that many students from administration concentrations perceive a negative learning climate.

The literature on workplace climate suggests that negative experiences have a particularly serious impact on well-being. Gant et al. (1993), for example, found that negative interactions, particularly those that involved undermining, had a stronger impact than positive interactions on workers' sense of mental health and accomplishment. Glisson and Hemmelgarn (1998) found that organizational climate was the main predictor of good service outcomes in their research on children's services. Thus, the impact of learning climate on students' sense of self-efficacy as well as their educational performance should not be underestimated. The cumulative effect may even have an undesirable impact on the profession. It is possible that at least some potential students of administration will turn their talents away from administration at a time when leaders in the field are needed, as they will listen to the "micro before macro" questions, and become fearful about limiting their careers.

Another consequence is perhaps more serious, but less recognized. The negative climates experienced in the professional education of both management and non-management students may exacerbate the gulf between managers and clinicians as MSW graduates move into agencies, further increasing the strain between the competing domains within organizations.

What, then, can and should be done to modify organizational climates within schools of social work? Schools of social work with administration/management concentrations can take 
the following modest steps. First, by bringing the issue into the open and making it a topic of discussion, it will be possible to conduct climate surveys to assess student perceptions of support for their career decisions and thereby provide feedback on important elements of organizational climate. Such surveys should include all students to determine if perceived lack of support is pervasive or specific to macro-practice students. Organization development literature suggests that feedback is sometimes sufficient as an intervention, as awareness that a problem exists can sometimes lead to behavior change (French \& Bell, 1995).

Second, when dysfunctional norms are more intractable, efforts to increase communication and team-building interventions - especially inter-group teams - may be needed to increase awareness to the level that induces change (French \& Bell, 1995). Structuring increased opportunities for communication and interaction across specialties, such as teamteaching of generalist practice courses, may be helpful.

Third, faculty development efforts should be undertaken to ensure that all faculty teaching foundation courses are able to draw on a range of both micro and macro practice examples. Our survey results suggest that this is an area needing serious attention, as the majority of students expressed significant dissatisfaction with the imbalance and lack of relevance of much of their foundation education.

Fourth, to enhance career support to macro practice students, it would be helpful to provide orientation to key personnel who deal with students at points of decision, such as admissions officers, advisors, and field placement coordinators. This effort should extend to field instructors of macro practice students to ensure that they do not undermine the focus of the administration or macro specialization. 
Fifth, if Neugeboren (1986) is right about the rationalization of micro-practice dominance through the movement to generalist practice, then intervention at standard setting and professional organization levels will be needed to more fully address the issues raised in this study. Efforts within the Council on Social Work Education should focus on re-examining the necessity of a generalist foundation and/or to redefining generalist to be more macro-inclusive. Macro-practice members of NASW should continue to press for a management section, and question the continued support of single-level, clinical specialist licensing bills that further cement the idea that "all social work practice is clinical".

Clearly, more research is needed to test the very preliminary findings of the study reported here. As suggested above, research on the organizational climate within schools of social work with a focus on student perceptions would be particularly valuable in suggesting the direction for optimal remedies.

While awaiting further research and school-wide climate-change efforts, faculty who work directly with administration concentration students can redouble their efforts to support the professional identity and career decisions of students by providing content on the history of administration within the profession, sponsoring seminars with agency leaders, and perhaps even engaging administration students themselves in designing OD strategies to address climatechange. 


\section{References}

Austin, D. (2000). Social work and social welfare administration: A historical perspective. In R.J. Patti (Ed.). The handbook of social welfare management (pp. 27-54). Thousand Oaks, CA: Sage, 27-54.

Biggerstaff, M. (1978). Preparation of administrators in social welfare: A follow-up study of administration concentration graduates. Administration in Social Work, $2,359-367$.

Dinerman, M. (1984). The 1959 curriculum study: Contributions of Werner W. Boehm. In M. Dinerman \& L. L. Geismar (Eds.) A quarter-century of social work education (pp. 3-24). National Association of Social Workers, ABC-CLIO, Council on Social Work Education,

Edwards, J.D. (undated). Managerial influences in public administration. University of Tennessee at Chattanooga, Department of Political Science. www.utc.edu/ mpa/managerialism.htm. Accessed 7/4/02.

Ezell, M. (1990). Social work's anti-management ideology. Paper presented at the Annual Meeting of the National Association of Social Workers, Boston, MA.

French, W.L. \& Bell, C.H. Jr. (1995). Organization development, 5th edition. Englewood Cliffs, NJ: Prentice-Hall.

Gant, Z.M., Nagda, B.A., Brebzin, H.V., Jayaratyne, S., Chess, W.A. \& Singh, A. (1993). Effects of social support and undermining on African-American workers: Perceptions of coworker and supervisor relationships and psychological well-being. Social Work, $\underline{38}(2)$, 158-64.

Gibelman, M. \& Shervish, P. (1997). Who are we? A second look. Washington DC: NASW Press. 
Glisson, C. (2000). Organizational climate and culture. In R.J. Patti (Ed.) The handbook of social welfare management (pp. 195-218). Thousand Oaks, CA: Sage Publications, Inc.

Glisson, C. \& Hemmelgarn, A. (1998). The effect of organizational climate and interorganizational coordination on the quality and outcomes of children's service systems. Child Abuse and Neglect, 22(5), 401-21.

Gummer, B. (1987). Are administrators social workers? The politics of intra-professional rivalry. Administration in Social Work, $\underline{11}(2), 19$ - 31.

Ife, J. (2001). Human rights and social work: Towards rights-based practice. Cambridge, UK: Cambridge University Press.

Kouzes, J. S. \& Mico, P. R. (1979). Domain theory: An introduction to organizational behavior in human service organizations. Journal of Applied Behavioral Science, 15(4), 449-469.

Lagay, B. (1983). The two cultures of social work. In Miriam Dinerman (Ed), Social work futures: Essays commemorating twenty-five years of the graduate school of social work (pp. 267 -281). New Brunswick, NJ: Rutgers University Press.

Lohmann, R. A. \& Lohmann, N. (2002). Social administration. NY: Columbia University Press.

Martin, M.E, Pine, B.A. \& Healy, L.M. (1999). Mining our strengths: Curriculum approaches in social work management. Journal of Teaching in Social Work. $\underline{18}$ (1/2), 73-97.

McNutt, J. (1995). The macro practice curriculum in graduate social work education: Results of a national study. Administration in Social Work, 19(3), 59-74.

Mabrey, T., Thompson, D.H. \& Halseth, J.H. (1996). Education in policy, planning and administration: Operating in a hostile environment. Paper presented at the Council on Social Work Education Annual Program Meeting, Washington, D.C., February, 1996. 
Neugeboren, B. (1986). Systemic barriers to education in social work administration. $\underline{\text { Administration in Social Work, }} \underline{10}(2), 1$ - 14.

Page, W. J. (1978). The manager vs. the social worker. Public Welfare, $\underline{36}$ (Summer), 8.

Patti, R. J. \& Austin, M. J. (1977). Socializing the direct service practitioner in the ways of supervisory management. Administration in Social Work, 1(3), 267 - 280.

Patti, R. J. (1983). Social welfare administration: Managing social programs in a developmental context. Englewood Cliffs, NJ: Prentice Hall.

Perlmutter, F. D. (1984). Social administration and social work education: A contradiction in terms? Administration in Social Work, $\underline{8}(3), 61-69$.

Pine, B.A. \& Healy, L.M. (1994). Is state licensing an obstacle to social work students' selection of macro practice as a specialization? In M.J. Austin \& J.I Lowe, (Eds.). Controversial issues in communities and organizations (pp. 267-273). Boston: Allyn \& Bacon.

Rees, S. \& Rodley, G. (Eds.). (1995). The human costs of managerialism: Advocating the recovery of humanity. Sydney: Pluto Press.

Schwartz, S. \& Dattalo, P. (1990). Factors affecting student selection of macro specializations. Administration in Social Work, 14(3), 83-96.

Turem, J. S. (1986). Social work administration and modern management technology. Administration in Social Work, 19(3), 15-24.

Yoo, J. (2002). The relationship between organizational variables and client outcomes: A case study in child welfare. Administration in Social Work, 26(2), 39-61. 
Table 1. Number and Percent of Administration Students by Year

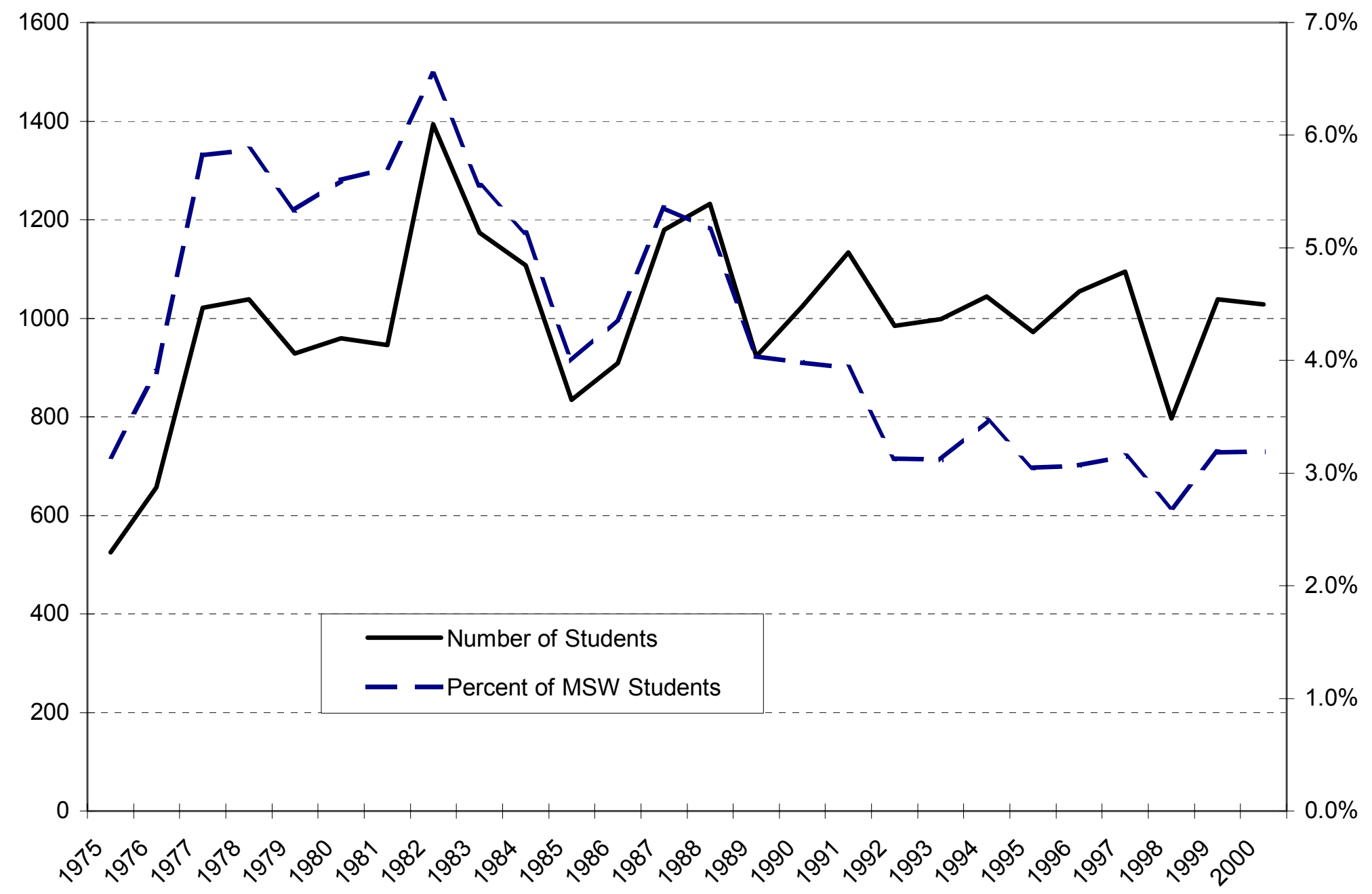


Table 1. School by school findings on student experiences when they selected administration concentrations, and their perceptions of anti-management attitudes.

\begin{tabular}{|c|c|c|}
\hline School & Reactions to Choice of Administration & Perceptions of Anti-management attitudes \\
\hline $\begin{array}{c}A \\
(n=11)\end{array}$ & $\begin{array}{l}\text { - Faculty and field supportive of choice. } \\
\text { - Half experienced criticism by students } \\
\text { - Warnings by community social workers that choosing } \\
\text { administration limits options }\end{array}$ & $\begin{array}{l}\text { More than half heard that administration is not real social } \\
\text { work; } 3 \text { from classmates, } 3 \text { in the field. } \\
\text { More than half heard anti-management comments from other } \\
\text { students. }\end{array}$ \\
\hline $\begin{array}{c}\text { B } \\
(n=17)\end{array}$ & $\begin{array}{l}\text { - Colleagues and supervisors prior to start of the program: } 7 \\
\text { reported support, } 5 \text { mixed comments, } 3 \text { experienced negative } \\
\text { or discouraging comments. } \\
\text { - Classmates: } 3 \text { reported support, } 3 \text { mixed but mostly negative } \\
\text { comments, } 7 \text { reported nonsupport. } \\
\text { - Non-administration faculty: respondents were evenly split } \\
\text { over whether these faculty were supportive. }\end{array}$ & $\begin{array}{l}\text { Eight respondents heard negative comments regarding } \\
\text { administration from field instructors, faculty, and students. } \\
\text { - Four reported being told that clinical training is best route to } \\
\text { administration. } \\
\text { - A number of students thought that faculty members' lack of } \\
\text { use of relevant examples in foundation courses was evidence } \\
\text { of anti-management attitudes (see Table 2). }\end{array}$ \\
\hline $\begin{array}{c}C \\
(n=28)\end{array}$ & $\begin{array}{l}\text { - Students routinely discouraged from selecting administration } \\
\text { concentration. }\end{array}$ & $\begin{array}{l}\text { - Many administration students experienced disparaging } \\
\text { remarks about administration. } \\
\text { - Respondents thought administration faculty eased the } \\
\text { situation somewhat. } \\
\text { - Many students felt the school only tolerated them as an } \\
\text { afterthought in a largely clinical curriculum. } \\
\text { - Reported that faculty viewed administration and agency } \\
\text { administration negatively. }\end{array}$ \\
\hline
\end{tabular}


Table 2. School by school findings on administration student perceptions of foundation classes and other related thoughts.

\begin{tabular}{|c|c|c|}
\hline School & Administration Students' Perceptions of Foundation & Other Related Thoughts \\
\hline $\begin{array}{c}A \\
(n=11)\end{array}$ & $\begin{array}{l}\text { Only two students in sample had taken foundation courses } \\
\text { but they felt the foundation provided very little relevant } \\
\text { background and very few administration or macro examples } \\
\text { were used. }\end{array}$ & \multirow{3}{*}{$\begin{array}{l}\text { - At one school, approximately one-third of the respondents } \\
\text { said current licensing arrangements made their choice of } \\
\text { administration very difficult. } \\
\text { - Respondents said some clinical students show hostility at the } \\
\text { idea that their administration classmates might be their } \\
\text { bosses, while, in their words, knowing less about practice. } \\
\text { - Some respondents report that some non-administration } \\
\text { students and faculty delight in reminding them that they } \\
\text { would not be able to find employment commensurate with } \\
\text { their job expectations or advanced social work education, and } \\
\text { would not be able to pass the state licensing exam. } \\
\text { At one school, when the students were asked if they had } \\
\text { second thoughts about their choice of concentration after } \\
\text { experiencing the anti-management climate, all but one } \\
\text { answered "no," and that one said that she might have } \\
\text { preferred another method of macro practice. } \\
\text { At one of the schools, the practicum coordinator asks those } \\
\text { who express interest in the administration, "Are you sure you } \\
\text { want to choose administration?" Many of the administration } \\
\text { students reported that this query concerned them and made } \\
\text { them wonder if they were making the right choice. }\end{array}$} \\
\hline $\begin{array}{c}B \\
(n=17)\end{array}$ & $\begin{array}{l}\text { - Respondents were critical of foundation courses with strong } \\
\text { feelings that foundation courses did not provide useful } \\
\text { background for their concentration studies. } \\
\text { - Use of examples: } 7 \text { reported that macro examples were rarely } \\
\text { or never used, } 5 \text { reported they were used in some courses but } \\
\text { not others, and } 3 \text { students reported that macro examples were } \\
\text { used to illustrate concepts in foundation courses such as } \\
\text { HBSE, Policy, Human Oppression and Ethics; }\end{array}$ & \\
\hline $\begin{array}{c}C \\
(n=28)\end{array}$ & $\begin{array}{l}\text { - Students expressed impatience and annoyance with the } \\
\text { content of required foundation courses; they thought it was a } \\
\text { waste of their time because that's not where they wanted to } \\
\text { be. } \\
\text { - Some students wondered whether the relatively little content } \\
\text { given on organizations and communities had been deliberate } \\
\text { to avoid "turning students on" to macro practice. } \\
\text { - Students reported that when they introduce macro } \\
\text { perspectives in class, the class generally becomes silent and } \\
\text { the instructor stares until it passes or it is said that the point } \\
\text { or question is not something that can be dealt with at the } \\
\text { time. }\end{array}$ & \\
\hline
\end{tabular}

